RESEARCH

\title{
A COMPARISON OF THE VIEWPOINTS OF DIFFERENT LEVELS OF NURSE MAN- AGERS ON EMPOWERMENT IN THEIR WORKPLACE
}

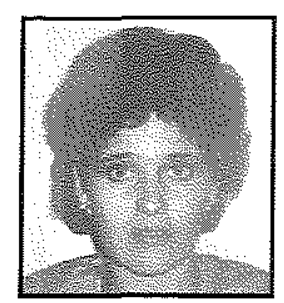

\author{
Karien Jooste \\ Senior lecturer, \\ Department Of Advanced Nursing Sciences, \\ University of South Africa
}

\begin{abstract}
Differences of opinion between the three levels of nurse managers on the subject of empowerment exist among nurses in health services. It was unclear how top, middle and functional level managers view their own role in the empowerment of their subordinates. The aim of the study was to identify the elements that are essential for the different levels of nurse managers to ensure an empowered nurse. A descriptive explorative study was undertaken in 1997 in Gauteng. A conceptual framework was evolved by analysing literature on the contributing elements of empowerment in nursing management. An instrument was developed, based on the elements, and was distributed to a sample of 487 top, middle and functional level nurse managers of 37 institutions, namely, provincial and private hospitals, as well as municipalities and clinics in Gauteng. An item analysis was used to test the reliability of the items in the questionnaire (Cronbach's alpha 0,919) and a factor analysis indicated the validity of the instrument to measure the concept of empowerment. The data analysis, by means of the chisquared test, indicated that significant differences of opinion existed between the three management groups regarding the concept of empowerment.
\end{abstract}

The results indicated differences of opinion between the three groups with regard to an effective organisational structure of a health service, the sharing of power with subordinates, the decisionmaking process, management skills of the nurse manager, motivation and reward strategies and characteristics of an empowered nurse manager in the empowerment of nurses. The conclusion is made that the higher a person/nurse is situated in the nursing hierarchy of a service, the more empowerment he/she experiences.

\section{OPSOMMING}

Verskille in opinies tussen die drie vlakke van verpleegbestuurders in gesondheidsdienste bestaan oor die kwessie van bemagtiging. Onduidelikheid het bestaan oor hoe top, middel- en funksionelevlak bestuurders hul eie rol in die bemagtiging van hul ondergeskiktes beskou. Die doel van die studie was on die elemente te identifiseer wat essensieël vir die verskillende vlakke van verpleegbestuurders om 'n bemagtigde verpleegkundige te verseker: 'n Beskrywende ondersoekende studie was in 1997 in Gauteng onderneem. ' $n$ Konseptuele raamwerk het tot stand gekom vanuit die analisering van literatuur oor die bydraende elemente van bemagting in verpleegbestuur. 'n Instrument was ontwikkel, gebaseer op dié elemente en versprei na'n steekproef van 487 top, middel en funksionelevlak bestuurders van 37 instansies, naamlik provinsiale en privaathospitale, asook stadsrade en klinieke in Gauteng. ' $n$ Itemanalise was uitgevoer om die betroubaarheid van die items in die vraelys te toets (Cronbach se 
alpha 0,919) en ' $n$ faktoranalise het die geldigheid van die instrument om die konsep van bemagtiging te meet, vasgestel. Die data-analise by wyse van die chi-kwadraat het daarop gedui dat betekenisvolle verskille in opinies tussen die drie bestuursvlakgroepe aangaande die konsep bemagtiging bestaan.

Die resultate het verskille in opinies tussen die drie groepe aangedui met betrekking tot ' $\mathrm{n}$ effektiewe organisatoriese struktuur van ' $n$ gesondheidsdiens, die deel van mag met ondergeskiktes, die besluitnemingsproses, die bestuursvaardighede van die verpleegbestuurder, motivering en beloningstrategieë en eienskappe van 'n bemagtigde verpleegbestuurder in die bemagtiging van verpleegkundiges. Die slotsom word gemaak dat hoe hoër ' $n$ persoon/verpleegkundige in die verpleeghiërargie van 'n diens geplaas is, hoe meer bemagtiging ervaar sodanige persoon.

\section{INTRODUCTION AND GENERAL BACK- GROUND}

Empowerment is a key ingredient in achieving a motivated and successful body of staff members in any health organisation. However, the current situation in health services indicates a situation in which nurses experience a lack of empowerment in their work situation. According to Klann (1992:20) the tendency over the last twenty years is the decreasing of authority and autonomy of nurses in health services. Empowered and motivated nurses are needed to actively participate in organisational activities to ensure quality nursing care, cost-effective service rendering, high morale and work productivity.

The empowerment of nurses has value for the nursing profession. Nurses who are empowered, show it by putting forward their creative ideas, accepting delegated responsibilities, promoting open discussions with colleagues and supervisors and being receptive to new ideas. The result is that nurses become active participants in the future planning of the service. Empowerment promotes the development of prospective nurse leaders who will be prepared for their task (Booyens, 1993:21).

Havens and Mills (1992:62) are of the opinion that nurses should be empowered in future by means of greater participation in the decision-making that directly affects them, that is participation in decisions regarding issues in their working environment and quality nursing care that they should deliver. Rapid changes take place continuously in, for example, the patient care delivering system in health services. In future, better qualified and equipped health staff are required to complete the more extensive managerial tasks in their working situation. To fulfill the last mentioned need and to meet the challenges of the future, managers should possess the necessary managerial skills and responsibilities and be empowering towards nurses.

It, however, seems that nurses worldwide are of the opinion that they have a lack of empowerment in their management practice. This leads to low work productivity and morale among nurses. Some hospitals are not prepared to reduce their control measures over nursing actions. Yet management of health services gives us to understand that they are prepared to empower nurses. This approach sends confusing messages to nursing staff. This again leads to mistrust in management and a general resistance against the management of the service (Manthey, 1991:16).

Among the different definitions on management empowerment, the following is an example: "Empowerment is the interpersonal process of providing proper tools, resources and environment to build, develop and increase the ability and effectiveness of others, to set and reach goals for individual and social ends" (Gibson, 1991:355). This definition is comprehensive but does not outline the specific elements and components of the concept of empowerment in the man- 
agement situation.

A study on empowerment of nurses by Jooste (1997:198) concluded by defining management empowerment as: "The nurse leader, with her unique characteristics and managerial skills, is in interaction with her environment, which includes management structures and employees, especially nurses in the organisation. The leader strives to use management structures by means of motivation strategies and participative decision-making to share power with nurses in the health service and to improve her own management expertise". This definition outlines the important main components to be addressed by the nurse managers in the empowering process of nurses.

De Villiers (1992:112) in her research study about a general managerial model for nurse managers, concludes that the public sector of health services in South Africa is bureaucratic-orientated with the emphasis on legitimate power and high and mightiness of top level management. This could influence the role of functional and middle level managers in addressing the essential components for empowerment of nurses.

\section{PROBLEM DESCRIPTION AND PURPOSE OF THE STUDY}

The concept empowerment is presumed in different forms by various persons and in different contexts (Perkins, 1995:777). Empowerment can thus not be described in a single way. The need exists that it should be described by the different role players involved with it (Gibson, 1991:355).

In the setting of a health service the systems of coordination and control exist within a hierarchy (Hall, 1990:113). The higher the position of a person in the command order, the bigger is her/his power basis and chances of being involved in critical activities and decision-making on the organisation (Hoelzel, 1989:11). Depending on the urgency of a decision that should be taken, a nurse manager can determine how much power she herself should maintain and how much power should be assigned to nurses for making the decision (Hall, 1990:114). Power sharing is thus related to the diminishing of the power exertion by a nurse manager. A manager or nurse lacking power can only deliver limited input in their work situation (Willey, 1990:189). It was not known if all nurse managers viewed and enacted their roles similarly in the sharing of power with nurses that is essential for the empowerment process.

According to Brown and Schultz (1991:37), strict control measures by top management in a service increase the potential for suppressing the ideas of lower level managers and nurses. This leads to high stress levels, which contribute to a lack in creativity, new ideas and motivation of staff members. A lack in empowerment leads to an unmotivated nursing corps and in turn to dissatisfaction of the users of health services. All levels of nurse managers should play active roles in the empowerment of nurses in their working situation. However, it seems that the hierarchy of a service influences the empowerment process. The main problem is that insufficient empowerment is experienced on the lower levels of the nursing hierarchy. Different levels of nurse managers will therefore view their roles in the empowerment of nurses, differently.

The purpose of the study was to identify the different opinions of top, middle and functional level nurse managers on their roles in ensuring empowerment of nurses in the daily work situation. It was assumed that nurse managers on different levels of the nursing hierarchy had different opinions and views on the empowerment of nurses in health services.

The objective of the study was to identify managerial weaknesses in the process of empowerment of nurses. Essential areas for the advancement of empowerment of nurses were identified. The viewpoints of nurse managers regarding the role of managerial structures, power sharing, decision-making, managerial skills, motivation and incentives, and characteristics of an empowering manager, were determined. 
Empowerment was viewed as a multidimensional concept, which can enhance work satisfaction of nurses and the quality of patient care.

\section{RESEARCH QUESTIONS}

From the main problem regarding the empowerment of nurses, the following research questions were stated for the top, middle and functional level managers:

- Which roles do managerial structures in their workplace play in the empowerment of nurses?

- Which role do managers play in power sharing of nurses?

- To what extent does participative decision-making contribute to the empowerment of nurses?

- Which managerial skills and responsibilities in the daily management task and task design contribute to the empowerment of a nurse?

- How do motivation and incentive systems contribute to the empowerment of a nurse?

- Which personal and leadership traits are characteristic of an empowering nurse manager?

\section{GENERAL RESEARCH HYPOTHESIS}

Arising from the research problem and research questions, the following comprehensive hypothesis was formulated:

The higher a nurse manager is positioned in the hierarchy of a health service, the more empowerment is experienced in her/his workplace to empower subordinates than managers on the middle and functional levels of the nursing hierarchy.

The research questions were re-formulated in the form of the following null hypothesis:

- There is no relation between managerial structures and the position of the nurse manager in the hierarchy.

- There is no relation between the extent to which participative management take place and the position of the nurse manager in the hierarchy.

- There is no relation between power sharing with nurses and the position of the nurse manager in the hierarchy.

There is no relation between the managerial responsibilities of the nurse manager in her/his daily management task and task design and the position of the nurse manager in the hierarchy.

- There is no relation between the use of motivation and incentive systems that contribute to the empowerment of a nurse and the position of the nurse manager in the hierarchy.

There is no relation between the personal and leadership traits that are characteristic of an empowering nurse manager and the position of the nurse manager in the hierarchy.

\section{LITERATURE REVIEW}

The way in which the managerial structures of health services appear, as well as the process through which these structures change and are maintained, influence each nurse in the organisation, as well as the organisation as a whole. The concept organisational structures refer especially to the allocation of tasks to individuals and sections, hierarchical relations between managers and subordinates and communication lines between members in the service (Noorderhaven, 1995:131; Kinlaw, 1995:19). It is desirable that persons nearest to the point of delivering are consulted, because they know best what is feasible or not.

Organisational management structures play a crucial role in the empowerment of nurses. If empowerment is to be realised, the following organisational changes should take place: less levels of control in a service, the establishment of open communication lines between management and nurses, a better distribution of information and the development of new ideas and expertise of all staff.

An empowered work place is where a team or group of individuals work effectively together to complete a task and are involved in participative management (Scott \& Jaffe, 1991:16; Sovie, 1990:24). Real empowerment occurs where the manager is prepared 
to provide the subordinate with the freedom and power to perform the task effectively (Keller \& Dansereau, 1995:130). Empowerment takes place by means of relationships in which one person, through power sharing, creates the opportunity for another to act effectively and the other party accepts this opportunity (Brown, 1991:11). In traditional hierarchical health services the majority of decisions about strategic changes in the service are taken by only a few at the top level (Vogt \& Murrell, 1990:29). Also, the problem solving and decision-making authority for clinical and management issues is centralised within the top management level (Manthey, 1991:16). Although this managerial style is economical, the results are passive and unenthusiastic workers, as well as slow adaptation to changes (Booyens, 1993:122).

Managers are responsible for the implementation of empowering strategies from top to functional level and should therefore possess certain managerial skills to accomplish empowerment (Keller, 1994:2; Mdongo, 1995:14; Wallace, 1993:13). The manager should effectively apply her managerial skills, daily, to create opportunities for nurses to improve their skills and knowledge and to participate in the management of the service.

Managers should create a motivational environment that empowers nurses (Chandler, 1991:36). Employers are, inter alia, motivated by incentive and acknowledgement systems that build pride and self value (Drew, 1992:18). Other factors that contribute to task motivation, are greater work ownership and identification of nurses with the organisation in which they work (Klann, 1992:20). The manager should assist and support nurses to believe in the importance of their work (Kanter, 1989:91). Effective leaders inspire others with the enthusiasm of their vision and in this way carry forward the feeling of an objective that should be obtained and pride in their work.

The nurse manager as leader should personally be empowered before she can empower others (Byham, 1992:12; Gunden \& Crissman, 1992:7). A manager can care for nurses by the establishment of a helpful relationship, based on cooperation, support, acknowledgement of uniqueness, focus on strong points, help to overcome weak points and assistance in stress situations (Gordon, 1991:15; Gutiérrez et al. 1995:535; Minnaar, 1994:96-97; Mokgohloa, 1995:3). It therefore seems that the manager should be sensitive towards the needs of others, before empowerment can actually take place.

\section{METHODS USED}

A quantitative descriptive explorative study was done within the South African context by means of an analysis of literature on the contributing elements of empowerment in nursing management. A conceptual framework for the study on management empowerment evolved with six main key concepts, which were identified, to direct the study. The six key components identified from the descriptions and definitions regarding empowerment evolved as:

(a) The organisational structures of the health care organisation.

(b) Participative decision-making in the empower ment of nurses.

(c) Motivation and reward strategies contributing to wards empowerment.

(d) The role of power sharing in the empowerment of nurses.

(e) Attributes that are characteristic of an empowered nurse manager.

(f) The management skills and responsibilities of the nurse manager in her daily task design and man agement contributing to the empowerment of nurses.

\section{VALIDITY AND RELIABILITY}

A questionnaire was developed, based on the six components which addressed the issues of empowering behaviour of all levels of nurse managers, and the ideal characteristics of, and elements in an empowering environment for nurses. Fifteen expert nurse managers as well as a statistician critically evaluated 
the instrument in a pretest. These nurse managers did not take part in the main study.

Face and content validity were ascertained by ex- 500 perts in the field of tertiary nursing education that critically viewed the questionnaire and recommended improvements. Content validity was tested by the items represented in the conceptual framework of 200 the study. Construct validity of the measuring instru- 100 ment was done by the process of factor analysis. The factor analysis displayed six factors that corresponded with the six initial constructs of the measuring tool and therefore confirmed that the instrument complied with the requirements for construct validity (Polit \& Hungler, 1993:252).

\section{POPULATION AND SAMPLING}

Eighty-two (82) provincial and private hospitals with 100 beds or more, as well as municipalities and clinics within health service departments, in the Gautengarea in South Africa, represented the population. The appropriate hospitals were identified from the Hospital Yearbook, 1993.

Top management of these health services was requested in writing to participate in the study. 37 Institutions of which 17 private hospitals, 12 provincial hospitals and 8 municipalities indicated their willingness to participate and therefore formed the accessible population.

The total number of nurse managers working in these 37 services were 690 respondents consisting out of 67 top, 201 middle and 422 functional level nurse managers. A census was done by means of the questionnaire.

A feedback of 72,5 percent of the total number of respondents was obtained (Figure 1). The study group for this study consisted of four hundred and eighty seven (487) respondents involving 36 top, 194 middle and 270 functional level managers.

\section{Figure 1: Feedback on questionaires}

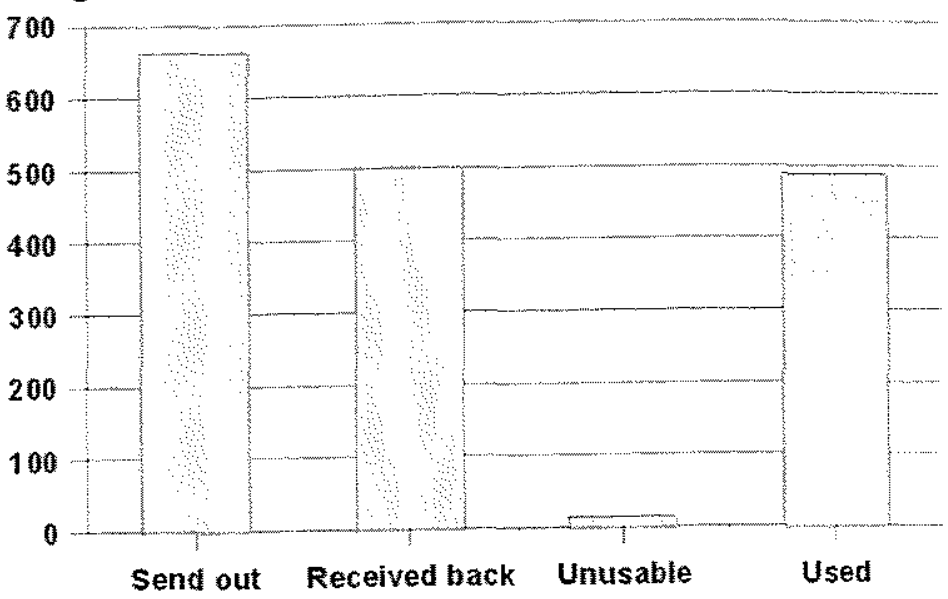

DATA ANALYSIS

Chi-quadrate tests were done to determine if signifi cant differences existed between the three levels of nurse managers regarding the responses on the items and to reject the stated null hypothesis. When comparing the three management groups regarding their responses on the different statements/items of the questionnaire, a significant level of 0,01 was used.

\section{FINDINGS, CONCLUSIONS AND RECOM- MENDATIONS}

A discussion on the viewpoints of the three levels of nurse managers on important items of the six components of empowerment, follows.

\section{Figure 2: Organisational structure}

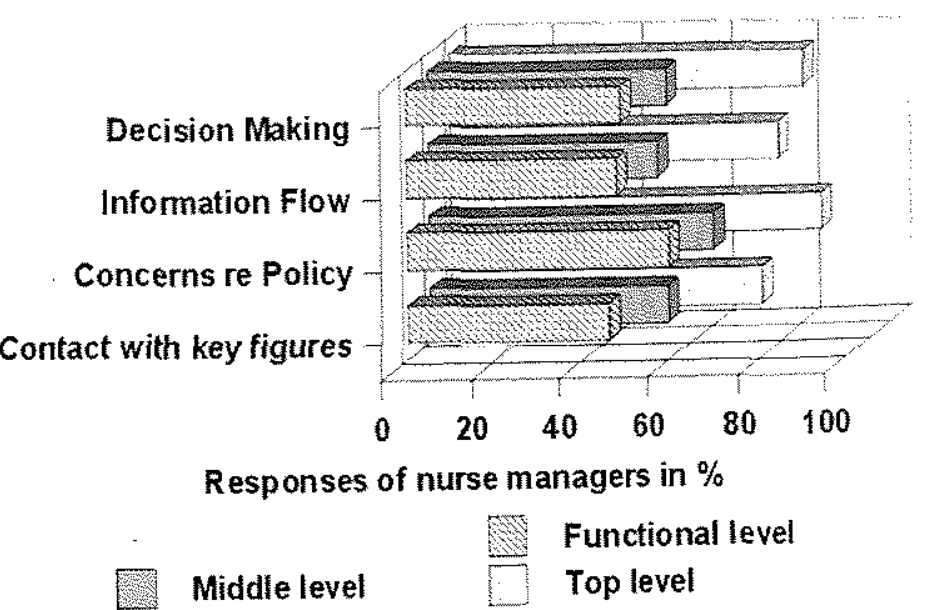


Organisational Structure

Significant differences of opinions were found in the responses of managers in all the services with regard to an open climate for discussion and criticism of policy, joint decision-making between managers and nurses and adequate access to the necessary information to deliver quality nursing care.

\section{Contact with key figures}

The findings indicated an interesting sequence, showing that the higher the position of the nurse manager in the hierarchy of the organisation, the more contact they have with important contact persons in the service. $(x 5(2, N=485)=29,9, p<.01)$

\section{Concerns re policy}

The lower the position of the nurse managers in the health service hierarchy, the less they felt free to forward their concerns regarding policy matters. They may have felt that they did not have the necessary power and say to influence the policy making process. $(x 5(2, N=477)=9,36, p<.01)$

\section{Information flow}

The higher the position of the nurse manager in the organisational structure the more information was available to him/her. It seemed that on each level of nurse managers certain information was not forwarded to the next level. Functional level managers therefore felt excluded from important information. $(\mathrm{x} 5(2, \mathrm{~N}=480)=13,42, \mathrm{p}<.01)$

\section{Decision-making}

Like information flow it was evident that, the higher the position of the nurse manager in the organisational structure, the more she was involved in decisionmaking. Only $47.06 \%$ of functional nurse managers experienced involvement in decision-making. ( $\mathrm{x} 5 \mathrm{(2}$, $\mathrm{N}=484)=14,40, \mathrm{p}<.01)$

The above four statements and responses on the theme organisational structure, indicate the presence of a strong bureaucratic managerial style in health services, where the functional level nurse lacks the opportunity for individual decision-making (Gunden \& Crissman, 1992). The null hypothesis regarding the managerial structures and the position of the nurse manager in the hierarchy was rejected. It could be accepted that top level managers are more empowered to make contact with key figures, give input in policy matters, have access to the necessary information and to participate in decision-making processes, than lower level managers and nurses.

Randolph (1995:22) also agrees that top level managers have access to a broad range of appropriate information in a service that they should give through to all persons, on all levels that fall under their authority.

In future, fundamental changes in management structures are needed to establish empowerment of nurses. Training in supervisory skills, an open climate for discussion, collaborative decision-making, opportunities for innovation and a two-way information system are necessary to empower nurses. Managers need contacts and networks, such as admission and interaction with important persons in the service (Chandler, 1991b:36-37; Kinlaw, 1995:89; Vogt \& Murrell, 1990:102). Managers with sufficient contact and interaction with top management possess the necessary managerial knowledge to support nurses effectively, by advising them about types of behaviour and contributions that are needed in nursing practice.

\section{Power Sharing}

Figure 3: Power sharing

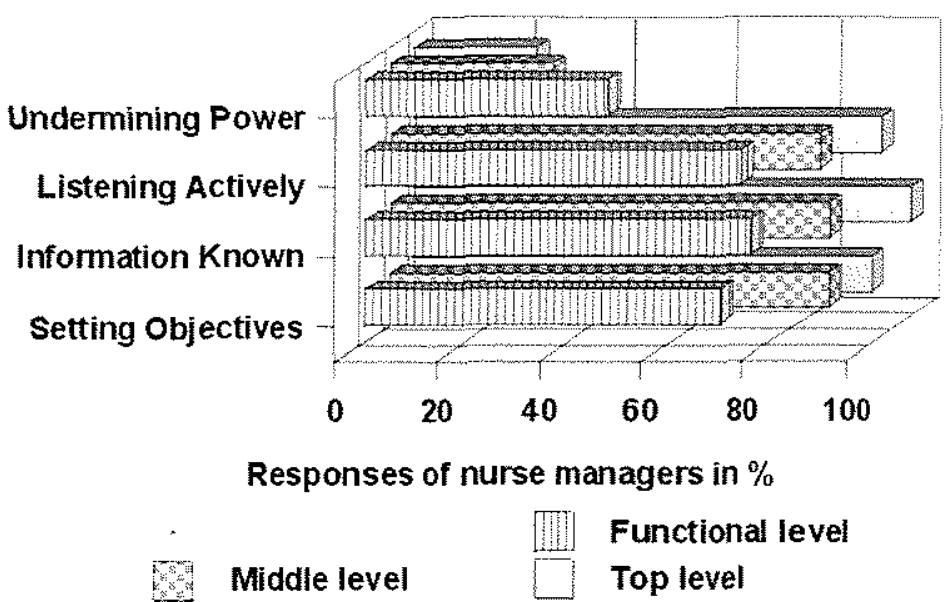


Significant differences of opinions were found in the responses of managers in all the services with regard to the managerial expertise of the nurse manager, the advocacy role of the nurse manager for staff at higher authority and the distribution of responsibility and authority to the lowest possible level.

\section{Setting objectives}

The statement was made that "power sharing occurs because the manager and the nurse set objectives together and then work together to obtain the set objectives". It seemed that power sharing was less of a problem at the top level managers because only a few managers share power at this level. It was at the middle and functional levels where many managers are involved, where the problem occurred (Abdel-Halim, 1993). $(x 5(2, N=484)=8,02, p<.01)$

\section{Information known}

Top level nurse managers were those who have the most information on unwritten rules of their services. $(\mathrm{x} 5(2, \mathrm{~N}=483)=6,28, \mathrm{p}<.01)$

\section{Listening actively}

The middle and top level nurse managers indicated that they paid attention to the proposals of enthusiastic nurses by actively listening to them, whereas functional nurse managers were in much lesser agreement than their seniors about this matter. Power sharing is thus needed at the functional management level. $(\mathrm{x} 5(2, \mathrm{~N}=484)=12,0, \mathrm{p}<.01)$

\section{Undermining power}

It was found that $47.64 \%$ functional level managers were of the opinion that superiors felt threatened if they permitted nurses to make too many decisions regarding important matters by themselves. Alternatively $32.12 \%$ middle and $25.0 \%$ top level nurse managers were of the same opinion. $(x ?(2, N=483)=$ $14,56, \mathrm{p}<.01$ )

It is concluded that the higher the position of the nurse manager in the hierarchy of the health service the more power she/he may share with subordinate man- agers and nurses. Hoelzel (1989:11) confirms this by stating that the higher the position of a person in the charge order, the greater is her/his power basis and chances to be involved in critical activities and the decisions of the organisation. The null hypothesis regarding the power sharing of the nurse manager with nurses and her/his position of the nurse manager in the hierarchy is thus rejected. According to Helton (1992:14) nurses and lower level managers can only be empowered if top level managers are willing to share power with them.

In the future power sharing should contribute to employee satisfaction and increased responsibility needed for the empowerment of nurses. Power sharing should involve effective advocacy of the manager, fair distribution of power, and effective distribution of responsibilities and authority to lower levels in the hierarchy. Nurses gain through power sharing by being more motivated, knowing that their work performances are recognised and contribute to improved service delivery (Kinlaw, 1995:43). Hall (1990:117118) emphasises that power should be fairly distributed between two parties to complete a task. The parties will then view one another as equals and both will accept the full responsibility for effectively performing the task.

\section{Participative Decision-making}

Figure 4: Decision-making

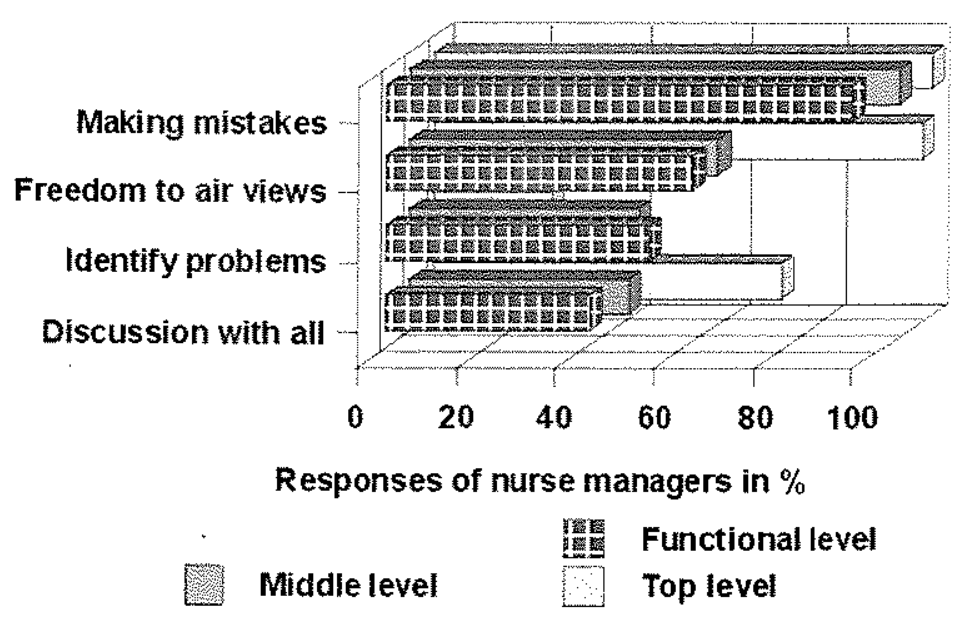

Significant differences of opinions were found in the responses of managers in all the services with re- 
gard to participation of nurses in decisions that affect their work situation, problem solving on the lowest possible level and promotion of team spirit

\section{Discussion with all}

It was mainly the functional and middle level managers who disagreed with the statement that "before top management implements a policy that affects nurses directly, it is first discussed at all levels in the service". It seems that the top level managers have the final say in decision-making and that their subordinates need more responsibility and decision-making power regarding policies affecting their daily work activities. $(\mathrm{x} 5(2, \mathrm{~N}=483)=9,86, \mathrm{p}<.01)$

\section{Identify problems}

It was found that especially the lower level of nurse managers felt that nurses can identify problems, but are not responsible for the solution thereof. (x $5(2, \mathrm{~N}$ $=482)=13,67, \mathrm{p}<.01$ )

\section{Freedom to air views}

The higher the level of the nurse manager in the hierarchy, the more they experienced that nurses revealed the freedom to air their views, on decisions that they disagreed with. $(x 5(2, \mathrm{~N}=481)=17,10, \mathrm{p}<.01)$. Hidden opinions or conflict may result in low employee motivation and increased anger (Dienemann, 1998:119).

\section{Making mistakes}

Nurse managers on the lower levels of the hierarchy are not exposed to the testing of alternative solutions as empowered behaviour, but must subject themselves to the policy statements in the service. ( 55 ( 2 , $\mathrm{N}=476)=12,70 \mathrm{p}<.01$ )

The conclusion made is that the higher the position of the nurse manager in the hierarchy of the health service the more empowered she/he is to make decisions in his/her working environment. The null hypothesis regarding the extent to which participative management takes place and the position of the nurse manager in the hierarchy is thus rejected. A number of authors confirm that the majority of decision-making processes are limited to top management level (Vogt \& Murrell, 1990:29; Manthey, 1991:16; Booyens, 1993:122). Burdett (1991:28) is of the opinion that managers limit the participation of nurses in decision-making, because of the risks involved. However, nurses should make decisions about the priority needs of their patients that include nursing care plans.

Chiles and Zorn (1995:6) argue that managers should learn to change their traditional ways of management to a style of participative management. In future the empowerment of nurses should focus on the elements of:

team spirit

constructive conflict management input of subordinates in decision-making the necessary authority to take independent decisions.

The multiple levels of bureaucratic approval for the solution of problems should be diminished, because it is necessary for the worker to react quickly to the changing and unpredictable needs of clients and patients. Speedy responses to problems diminish the loss of time and money for the health service (Alcorn, 1992:13; McGraw, 1992:16). Nurses should actively participate in the decision-making process, whereas managers should act as facilitators and supporters rather than supervisors and controllers (Hibberd et al. 1992:13).

\section{Management Skills And Responsibilities of The Nurse Manager}

Figure 5: Management skills

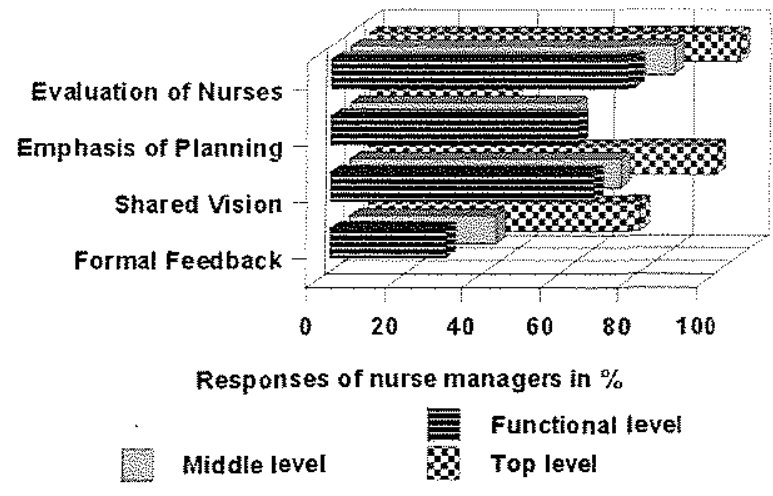


Significant differences of opinions were found in the responses of managers in all the services with regard to constructive evaluative feedback about work performances, the existence of a vision for the service and participation of nurses in the planning of projects.

\section{Formal feedback}

The first and middle level managers, experienced a lack of opportunity for feedback on their experiences regarding the managerial style of the nurse manager. $(\mathrm{x} 5(2, \mathrm{~N}=478)=20,86, \mathrm{p}<.01)$

\section{Shared vision}

The lower level managers did not value the vision of the services to the same extent as the top managers. $(\mathrm{x} 5(2, \mathrm{~N}=479)=7,69, \mathrm{p}<.01)$. Nurses could possibly be ignorant of the vision of their service.

\section{Emphasis of planning}

It was interesting to note that especially the lower level of the nurse managers was of the opinion, that the emphasis on planning is the attainment of greater cost-effectiveness rather than the development of staff members. (x5 $(2, \mathrm{~N}=484)=10,79, \mathrm{p}<.01)$

\section{Evaluation of nurses}

Top level management, experienced evaluation of the performance of nurses as a positive experience that contributes to growth whereas functional level managers experienced the opposite. $(x 5(2, N=482)=$ $8,32, \mathrm{p}<.01)$

It is concluded that the top level manager has more managerial responsibilities in her daily task design than functional level managers. The null hypothesis that stated the non-existence of a relation between the managerial responsibilities of the nurse manager in her/his daily management task and task design and the position of the nurse manager in the hierarchy, is thus rejected. The conclusion is confirmed by a statement of Hegland (1992:54) that some managers find it difficult to give up control and then make the fault of exercising too much and too strict supervision over personnel. Top level managers do not always give nurses and lower level managers the opportunity to use the skills and knowledge that they acquire during training, because they would rather handle the issues themselves by holding on to the responsibility and authority of the tasks (Booyens, 1996:5). Nurses need constructive feedback to correct their behaviour in their work place (Gilbert \& Nelson, 1991:13).

In the future all managers should address the existence of a vision and mission in a service, participation of nurses in the planning of projects, setting of objectives collaboratively, constructive feedback, a managerial climate that promotes independence in the workplace and effective supervision and control. The existence of a vision in a service should focus the attention on the attainment of a goal that guides the work performances of nurses and promotes their commitment to the service. Nurses need the presence of managers in their work place who do not interfere with their work performances, only when asked for (Booyens, 1996:5).

\section{Motivation And Reward Strategies}

\section{Figure 6: Motivation and reward}

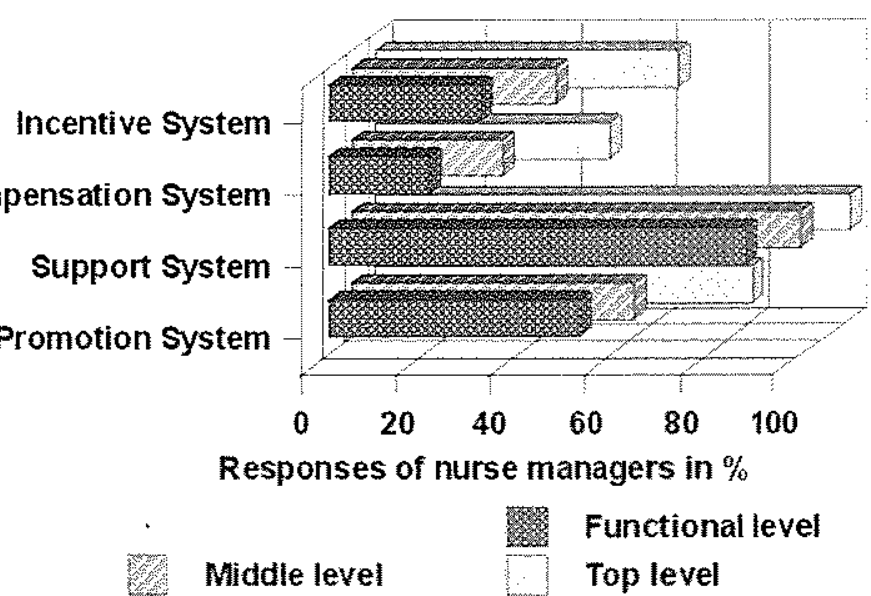

Significant differences of opinions were found in the responses of managers in all the services with regard to continuing constructive feedback to nurses and acknowledgement of nurses for excellent work done. 


\section{Promotion system}

It seemed that the lower the position of a nurse manager in the organisational structure, the more negatively she/he reacted towards the existing promotion system. $(x 5(2, N=479)=9,78, p<.01)$

\section{Support system}

The lower the level of the nurse managers in the hierarchy the less aware they were about the fact that nurses who are regularly supported by nurse managers in their work performance, develop a perceivable feeling of self-worth. $(x 5(2, N=472)=$ $9,72, \mathrm{p}<.01)$

\section{Compensation system}

Only a small number of first and middle level management and only approximately $50 \%$ of the top level managers were of the opinion that when nurses perform better than expected, they received the appropriate compensation. This clearly indicates the absence of a significant compensation system that contributes to the feeling of powerlessness among nurses. $(\mathrm{x} 5(2, \mathrm{~N}=483)=15,72, \mathrm{p}<.01)$

\section{Incentive system}

The same tendency was found in the item regarding a reward system. More top level managers than lower level managers were of the opinion that a reward system existed, where nurses who aim at the attainment of organisational goals rather than fulfilling personal goals, were acknowledged. $(x 5(2, N=482)=$ $15,35, \mathrm{p}<.01)$

The conclusion that could be made is that the lower the position of a manager in the hierarchy the less motivation and incentive strategies are viewed and used. The null hypothesis regarding the use of motivation and incentive systems that contribute to the empowerment of a nurse and the position of the nurse manager in the hierarchy is rejected. According to Du Rand \& Vermaak (1995:29) individuals who experience inadequate incentives feel a lack of empowerment. In a research study by Koch (1992:244) it was suggested that attention should be given to the job satisfaction of nurses, acceptance of nurses as unique human beings and incentive mechanisms.

In future strategies for the empowerment of nurses should focus on self motivation, expansion and enrichment of tasks, acknowledgement of work performances of nurses, rewards for outstanding service and constructive feedback by managers to nurses. The role of the nurse manager in motivation is more than merely being a role model, it also includes being available during work performances as a coach, to give advice and to help (Vogt \& Murrell, 1990:34). According to Kinlaw (1995:78) empowered individuals require more frequent feedback about their work performances.

Drew (1992:18) is also of the opinion that it is important to acknowledge the quality of nursing behaviour and quality performance. Expert individuals may receive an incentive by giving them the choice on which project should next be started (Kanter, 1989:91).

\section{Characteristics Of An Empowered Nurse Man- ager}

\section{Figure 7: Characteristics}

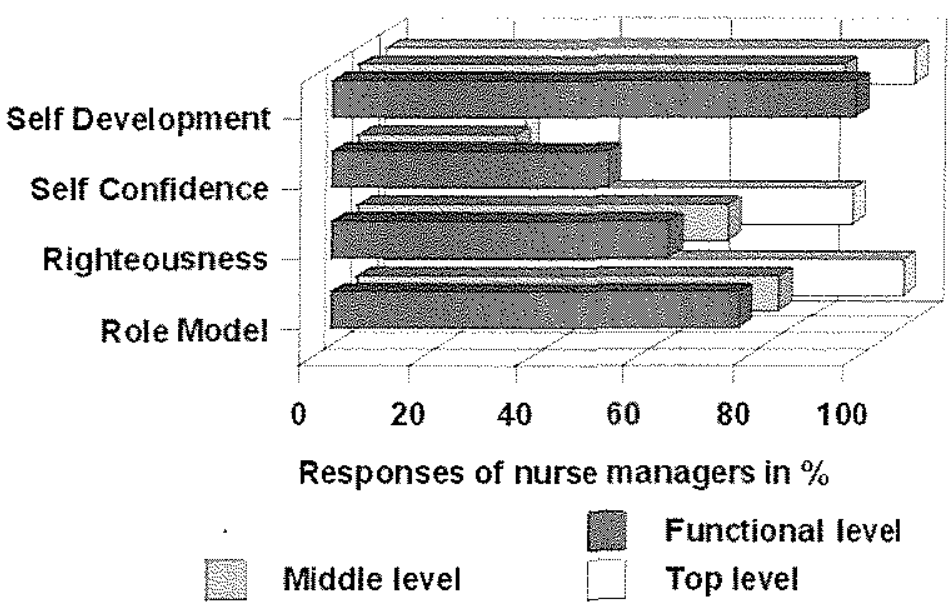

Significant differences of opinions were found in the responses of managers in all the services with regard to the characteristics of an empowered nurse manager. 


\section{Role model}

The higher the nurse manager's position in the nursing hierarchy the more they agreed that the nurse manager behaved in the same way that she expected nurses to behave. This could be ascribed to the fact that a nurse manager becomes more aware of her responsibilities and behaviour as she climbs the career ladder. $(\mathrm{x} 5(2, \mathrm{~N}=478)=6,42, \mathrm{p}<.01)$

\section{Righteousness}

Nurse managers at the functional and middle level experienced it less than top level management that, equal opportunities existed for each nurse to maximise her potential. $(x 5(2, N=480)=8,0, p<.01)$

\section{Self confidence}

The top and middle level managers showed considerably more insight than the functional level managers regarding entrusting tasks to nurses who lacked self confidence, in order to empower them. (x $5(2, \mathrm{~N}$ $=479)=25,07, \mathrm{p}<.01$ )

\section{Self development}

Top level managers agreed more than functional level nurse managers that the nurse manager should work actively towards her own self development by using the appropriate strategies for career progression. Self development with regard to skills and knowledge is an attribute that is characteristic of an empowered nurse manager (Boyadjis, 1990). $(x 5(2, \mathrm{~N}=475)=$ $7,53, \mathrm{p}<.01)$

It is concluded that there is a relation between the personal and leadership traits that are characteristic of an empowering nurse manager and the position of the nurse manager in the hierarchy. The higher the nurse manager is positioned in the health service the more empowering characteristics can be associated with her. Bezuidenhout (1994:242) confirms that power acquired by means of knowledge and skills, is one of the strongest forms of power. The more knowledge a manager possesses, the more power is possessed, which leads to the more effective empowerment of nurses. It thus seems that functional level managers need more empowering characteristics than top level managers do to effectively empower nurses.

It is recommended that the future empowering manager should possess the characteristics of a role model, fairness, expert behaviour, trustworthiness, be hard working, caring and open to criticism. According to Minnaar (1994:96-97) all managers should be role models who demonstrate caring by means of a helping relationship in which they accompany their subordinates with self confidence to professional maturity.

From the above discussion and rejection of the null hypotheses it is apparent that the higher a person is situated in the nursing hierarchy of a service the more empowerment he/she experiences.

\section{CONCLUSION}

Every nurse manager should have the opportunity to promote challenging situations for each nurse in her service and should realise their fullest potentials. All nurses should have the opportunity to be empowered. The discussion on viewpoints of the three levels of nursing managers outlines the current scenario of empowerment of nurses in health services in Gauteng and serves as guidelines to improve the working situation of lower level managers and nurses. Every nurse manager should create a new future for his/her organisation. In our rapidly changing health environment, pro-active planning of empowering nurses, is the best option offered for avoiding a society of unmotivated and dissatisfied nurses.

\section{REFERENCES}

Abdel-Halim, AA 1993: Power equalization, participative decision-making and individual differences.

Human Relations, 36(8):683-704.

Alcorn, DS 1992: Dynamic Followership: Empowerment at work. Management quarterly, 33(1):9-13. 
Ameigh, AY \& Billet, H 1992: Caring: A key to empowerment. Nursing Administration Quarterly, $16(3): 43-46$.

Bezuidenhout, MC 1994: The contribution of the nurse manager to industrial relations in selected hospitals. Doctoral thesis for D.Litt. et Phil. Pretoria: Unisa.

Booyens, SW 1993: Intreerede: Bemagtiging: 'n Verpleegbestuurperspektief. Pretoria: Unisa.

Booyens, SW (ed.) 1996: Introduction to Health Services Management. Juta: Cape Town.

Booyens, SW (ed.) 1998: Dimensions of Nursing Management. Juta: Cape Town.

Booyens, SW 1999: Empowerment: A nursing management perspective. Health SA Gesondheid, 4(2), July 1999:3-6.

Boyadjis, G 1990: Empowerment managers promote employee growth. Healthcare Financial Management, 44(3):58, 60, 62 .

Brown, CL 1991: Empowering others benefits all. The Florida Nurse, 39(2):11.

Brown, CL \& Schultz, PR 1991: Outcomes of power development in work relationships. Journal of Nursing Administration, 21(2):35-39.

Burdett, JO 1991: What is empowerment anyway? Journal of European Industrial Training, 15(6):23-30.

Byham, WC 1992: Would you recognize an empowered organization if you saw one? Tapping the Network Journal, 3(2):10-13.

Chandler, GE 1991: The workplace: On good mothers and good managers. Nursing Management, 22(12), December:36-37.
Chiles, AM \& Zorn, TE 1995: Empowerment in organizations: Employees' perceptions of the influences on empowerment. Journal of Applied Communication Research, 23(1):1-25.

Clifford, PG 1992: The myth of empowerment. Nursing Administration Quarterly, 16(3):1-5.

Dalton, C 1990: The sleeping giant awakes. The Canadian Nurse, 1990:17-18.

De Villiers, MC 1992: 'n Model vir bestuursinteraksie in ' $\mathrm{n}$ verpleegdiens. Proefskrif vir D.Cur. Randse Afrikaanse Universiteit: Johannesburg.

Dienemann, JA 1998: Nursing Administration. Managing patient care; 2 nd edition. Stamford: Appleton \& Lange.

Drew, EH 1992: Winning with quality values, in the 75th Symposium Series - Leadership and empowerment for total quality, Report number 992, pp.17-18. New York: The Conference Board

Du Rand, PP \& Vermaak, MV 1995: Houding, kennis en geluk van verpleegpersoneel wat in tehuise van bejaardes werksaam is. Curationis, 18(1), Maart:26 $-33$.

Gibson, CH 1991: A conceptual analysis of empowerment. Journal of Advanced Nursing, 16:354-361.

Gilbert, GR \& Nelson, AE 1991: Beyond participative management. Toward total employee empowerment for quality. New York: Quorum.

Gunden, E \& Crissman, S 1992: Leadership skills for empowerment. Nursing Administration Quarterly, 16(3):58-64.

Greenacre, MJ 1993: A correspondence analysis in practice. London: Academic Press.

Gutiérrez, L; Glen Maye, L \& De Lois, K 1995: The 
organizational context of empowerment practice: Implications for social work administration. Social work, 40(2), March 1995:249-258.

Hall, J 1990: Models for management. The structure of competence. Classic theories and facts about managing people featuring integrating research; 2 nd edition. Woodlands: Woodstead.

Havens, DS \& Mills, M 1992: Staff nurse empowerment: Current status and future projections. Nursing Administration Quarterly, 16(3):58-64.

Hegland, A 1992: Fine tuning management skills. Empowering staff improves harmony. Contemporary-Longterm Care, 15(7):53-54.

Helton, AS 1992: Leadership through empowerment. Texas Nursing, 66(1):14.

Hoelzel, CB 1989: Using structural power sources to increase influence. Journal of Nursing Administration, 19(11):10-15.

Kanter, RM 1989: The new managerial work. Harvard Business Review, November/December:85-92

Keller, B 1994: Nurse empowerment: Increasing the nurse manager's ability to delegate authority. Recruitment and Retention Report, 7(3):1-4.

Keller, T \& Dansereau, F 1995: Leadership and empowerment: A social exchange perspective. Human Relations, 48(2):127-146.

Kinlaw, DC 1995: The practice of empowerment. Making the most of human competence. Engeland: Gower.

Klann, S 1992: Empowered teams build participative system. OR-Manager, 8(2):20-21.

Koch, S 1992: Die bydrae van die verpleegdiensbestuurder tot koste-effektiwiteit in geselekteerde hospitale in die Republiek van SuidAfrika. Proefskrif vir D Litt et Phil: Unisa.

Manthey, M 1991: Empowering staff nurses: decision on the action level. Nursing Management, 22.

McGraw, JP 1992: The road to empowerment. Nursing Administration Quarterly, 16(3):16-19.

Mdongo, L 1995: Empowering employees: creating energy for continuous improvement. Human Resource Management, 11(2):14, 16.

Minnaar, A 1994: Die aard van sorg aan verpleegpersoneel, 'n Verpleegbestuurs-perspektief. MA Cur Verhandeling. Unisa.

Mokgohloa, T 1995: Empowerment - A people-driven process. Social Work Practice, 1, March:2-4.

Nolan, T; Goodstein, L \& Pfeiffer, JW 1993: Plan or Die! 10 keys to Organizational Success. San Diego: Pfeiffer.

Noorderhaven, $N$ 1995: Strategic decision making. England: Addison-Wesley.

Randolph, WA 1995: Navigating the journey to empowerment. Organizational Dynamics, 23(4):19-32.

Scott, CD \& Jaffe, DT 1991: Empowerment. Building a committed workforce. London: Kogan Page.

Sovie, MD 1990: Redesigning our future: whose responsibility is it? Nursing Economics, 8(1):21-26.

Thier, MJ 1989: Have you been empowered? Journal of Quality and Participation, pp.10-11.

Van Niekerk, SE 1999: Leadership: A tool for organisational empowerment in nursing education. Health SA Gesondheid, 4(2):7-11. 
Vogt, JF \& Murrell, KL 1990: Empowerment in organizations. How to spark exceptional performances. Santiago: Pfeiffer.

Wallace, GW 1993: Empowerment is work, not magic. Journal of Continuing Education, pp.10-14.

Willey, E 1990: Acquiring and using power effectively. Journal of Continuing Education, 18(1):25-28. 